\title{
Turismo de base comunitária: uma possibilidade no Morro do Vidigal (Rio de Janeiro, Brasil)?
}

\author{
Community-based tourism: a possibility in Morro do Vidigal \\ (Rio de Janeiro, Brazil)?
}

\author{
Lívia da Silva Godinho (GODINHO, L. da S.) ${ }^{*}$ \\ Viviane Soares Lança (LANÇA, V. S.) ${ }^{* *}$
}

\begin{abstract}
RESUMO - Neste estudo se aponta, de modo exploratório, a realidade do turismo comunitário em uma das principais favelas do Rio de Janeiro (Brasil), o Vidigal. Favela que tem se tornado, por vezes, local permanente de moradia de um número elevado de visitantes. A metodologia do trabalho foi baseada em visitas de campo com observação não participante, entrevistas semiestruturadas com moradores locais escolhidos aleatoriamente para melhor andamento da pesquisa e, ainda, pesquisas bibliográficas, referentes ao Turismo de Base Comunitária, feitas a partir da visão de autores e jornalistas que se dedicaram ao estudo das comunidades cariocas. Durante a execução do trabalho foi possível encontrar, entre outros resultados, as seguintes implicações: presença de projetos sociais na comunidade, forte cooperação dos moradores a estes projetos, alguns desafios após a implantação da Polícia Pacificadora e outros entraves, apresentados no artigo, que dificultam o adequado desenvolvimento do turismo na localidade.
\end{abstract}

Palavras-chave: Turismo; Turismo de base comunitária; Favela; Morro do Vidigal.

ABSTRACT - This study points to the reality of community tourism in one of the main favelas of Rio de Janeiro (Brazil), Vidigal. Favela has been the target of many tourists, becoming a permanent place of residence for a large number of visitors. The methodology of the study was based on field research, with local visitation, random interviews with local residents to improve the study progress and researches related to community based tourism, based on the view of authors and journalists who were dedicated to the study Of the Carioca communities. During the execution of the work, the following implications could be found: social projects in the community, strong cooperation of the residents in these projects, some challenges after the implementation of the peacekeeping police and certain obstacles, presented in the article, which make it difficult. The proper development of tourism in the locality.

Key words: Tourism; Community-based tourism; Favela; Morro do Vidigal.

\footnotetext{
* Formação: Graduação em Turismo (Bacharelado) pelas Faculdades São José. Atividade profissional: Consultora de viagens no Hotel Urbano. Endereço físico para correspondência: Caminho do Areal, n. 7, Guaratiba - Campo Grande. CEP: 23042-680 - Rio de Janeiro - Brasil. E-mail: livgodinho2@ gmail.com

** Formação: Graduação em Turismo (Bacharelado) pela Universidade Federal Rural do Rio de Janeiro (UFRRJ); MBA em Gestão Hoteleira pela Universidade Federal Rural do Rio de Janeiro (UFRRJ); Mestrado em Ciências pelo Programa de Pós-Graduação de Ciências Sociais em Desenvolvimento, Agricultura e Sociedade - CPDA/UFRRJ. Atividade profissional: Docente do curso de Turismo das Faculdades São José; Instrutora do Serviço Nacional de Aprendizagem Comercial - SENAC. Endereço físico para correspondência: Rua Carlos Chagas, 240 - Bairro da Luz. CEP: 26260-150 - Nova Iguaçu Rio de Janeiro - Brasil. E-mail: lanca.viviane@gmail.com
} 


\section{INTRODUÇÃO}

Constata-se que a cidade do Rio de Janeiro recebe turistas de muitos lugares, abrigando diversidades de cultura e beleza. Além das inúmeras praias e de dois ícones geográficos de grande relevância, o Corcovado e o Pão de Açúcar, o Rio vem disponibilizando um expressivo número de atrativos culturais e gastronômicos, contando também com o aumento da rede hoteleira na cidade (GOMES, 2016). Em pesquisa de Demanda Turística publicada pelo Ministério do Turismo (BRASIL, 2015), $30 \%$ dos visitantes que buscaram o Rio de Janeiro vieram motivados por atrações relacionadas a sol e praia. Em seguida vem a Cultura como fator de motivação para $15 \%$ dos entrevistados.

O principal segmento turístico do Rio é o turismo de lazer, com 45,2\% do total de visitantes recebidos, segundo a pesquisa de Demanda Internacional realizada pelo Ministério do Turismo (BRASIL, 2016). Neste mesmo estudo, em segundo lugar, o turismo de negócios aparece com 27,5\%. De acordo com tal pesquisa, 1,5 milhão de estrangeiros passaram pelo Rio no ano de 2014. Enquanto que em 2015, foram 6 milhões.

O Turismo, se adequadamente planejado, pode gerar oportunidades de trabalho e renda, capaz de contribuir para diminuição das desigualdades sociais. Neste quesito, vem se destacando, no Rio de Janeiro, o Turismo de base comunitária (TBC), que consiste em oferecer ao turista uma imagem humana da localidade a partir das experiências dos próprios autóctones. (BRASIL, 2009).

Neste segmento, o turista pode acompanhar o dia a dia do morador, contribuindo para o desenvolvimento da comunidade, de maneira econômica, cultural e socialmente. O TBC tem uma grande influência sobre o visitante que escolhe fazê-lo, pois tal experiência é marcada como meio de interagir com pessoas e culturas diferentes, mostrando ao turista uma maneira diferenciada de absorver os costumes locais. No Rio de Janeiro, por exemplo, a partir de trabalho de campo, verificou-se que os habitantes, em diversas atividades turísticas, estavam ensinando ao visitante a sua cultura, permitindo que as pessoas interagissem facilmente umas com as outras, o que acabava estabelecendo trocas mútuas de aprendizado. 
Uma das comunidades que, ente outras modalidades, desenvolve esse tipo de turismo no Rio de Janeiro é a da favela do Vidigal. Localizada na zona Sul da cidade, um bairro que fica entre o Leblon e São Conrado, sobre o morro Dois Irmãos, a comunidade está entre as favelas a que mais abriga turistas por influência de suas paisagens, artistas e estrangeiros que compraram casas na comunidade devido à popularidade da mesma (MIRANDA; FORTUNATO, 2016). Do topo do morro se pode apreciar uma das vistas mais privilegiadas da cidade do Rio, além de ser o local onde se encontra o maior número de hospedagem e estabelecimentos de gastronomia, conforme foi possível constatar por observação própria.

O Vidigal reserva ao visitante uma mescla entre moradias populares e uma natureza abundante. "[...] a favela nos ensina que uma viagem, para se tornar inesquecível pelos motivos certos, depende menos do glamour do destino do que da cumplicidade da companhia." (FREIRE-MEDEIROS, 2009, p. 15).

Em visita de campo, em conversa com alguns moradores da comunidade do Vidigal, obteve-se a informação de que o bairro estava abrigando turistas durante todo o ano, virando até moradia de alguns. Construções de pousadas comunitárias, também de acordo com informações de moradores, estavam contribuindo para a ocorrência do turismo. Assim como, ações comunitárias também estavam fazendo parte do desenvolvimento turístico no morro, como: o teatro Nós no Morro e a escola de moda Casa Geração.

As comunidades no Rio de Janeiro abrigam e possibilitam a muitos turistas observar a diversidade dos brasileiros e a realidade de moradores locais. Por isso, o objetivo deste trabalho foi o de mostrar a ação que o Vidigal trazia, a partir do turismo de base comunitária, quanto às ideias de lazer para o turista, bem como as vantagens e desvantagens desse turismo para a economia e desenvolvimento locais.

Como objetivos específicos, teve-se como intenção abordar as principais funções do Turismo de base comunitária na Favela do Vidigal no Rio de Janeiro; indicar a segurança e as polêmicas que estavam envolvendo o alto do morro e os moradores; e comentar sobre as riquezas do local, paisagens e projetos que valorizassem moradores e visitantes.

Para tanto, o método de pesquisa escolhido baseou-se em revisão bibliográfica, trazendo as ideias de autores sobre o tema abordado, servindo como destaque para 
enfatizar o que se entendia sobre o assunto. Utilizou-se, ainda, de visita a campo a fim de realizar um diário de bordo com informações acerca do convívio entre anfitriões e visitantes, e, ainda, entrevista com moradores e turistas do morro do Vidigal para capturar diferentes informações acerca das oportunidades que o TBC estava trazendo para todos os envolvidos.

O tema abordado tem a ver com a curiosidade das autoras em aprender e mostrar como o turismo pode se transformar em um projeto harmônico entre receptores e visitantes. Atrelado a este fato, o ápice do interesse nesse tema se deu com os projetos comunitários, internos e externos ao Morro como: trilha Dois Irmãos, festas nos albergues, visitação aos ateliês e teatro Nós no Morro, entre outros. Projetos estes que possibilitam entre turista e morador a criação de vínculo e manutenção do mesmo, a partir da vivência de experiências que contribuem para a promoção do TBC na comunidade.

\section{RIO DE JANEIRO: DOS DIVERSOS SEGMENTOS TURÍSTICOS AO TURISMO DE BASE COMUNITÁRIA}

O Rio de Janeiro é uma cidade de grande atratividade não só para estrangeiros, como também, para brasileiros. A Empresa de Turismo do Município do Rio de Janeiro - RIOTUR (2015) fez um levantamento do número de visitas em pontos turísticos nos anos de 2012, 2013 e 2014. Em 2012, o total de visitas nos pontos turísticos no Rio foram de 2.685.995. O Pão de Açúcar teve 54\% da procura, Corcovado 33\%, Museu Imperial 11\% e o Maracanã 2\%. Em 2013, a visitação nos pontos foram de 2.842.618, o Pão de Açúcar recebeu 52\%, Museu Imperial 10\%, Corcovado 32\%, Museu de Arte Contemporânea - MAC 6\%, o Maracanã esteve fechado durante esse período de 2013. Em 2014, o número de visitantes foi de 3.991.953, Pão de Açúcar com 39\%, Corcovado 44\%, MAC 3\%, Maracanã e Museu Imperial com 7\% das visitas.

Segundo o Ministério do Turismo (BRASIL, 2009), o produto turístico brasileiro tem um potencial muito avançado devido a diversidade da sua cultura e das inúmeras belezas naturais. Por este motivo, o Programa de Regionalização do Turismo Roteiros do Brasil, iniciado com a cooperação de representantes dos órgãos de turismo 
municipais e estaduais, indica os tipos de segmentos turísticos desenvolvidos no Brasil. "Através deste programa foram construídos critérios a fim de definir municípios que concebem os "pontos turísticos", de forma a sempre promover a sustentabilidade do local, a inclusão e a diversidade de cada uma das regiões turísticas" (BRASIL, 2013, p. $17)$.

Entre os segmentos que integram o Programa, há um que se caracteriza como sendo o acesso para regiões e ou roteiros em que comunidades receptoras assumem o papel de atores principais na oferta dos produtos e serviços turísticos. De acordo com o Ministério (BRASIL, 2016), esses produtos e serviços ofertados pelas comunidades locais são denominados de "turismo de base comunitária" (TBC) sendo ainda um segmento pouco conhecido, todavia mostra-se visível como campo de estudo.

Conforme o Ministério do Turismo (BRASIL, 2013, p. 31) o turismo de base comunitária consiste em "atividades e iniciativas protagonizadas pela população local que, se ordenadas e bem estruturadas, representam importantes experiências turísticas, agregando valor aos roteiros e geram empregos e renda para a região". Sendo um segmento que cresce a cada dia na cidade do Rio, pois muitos turistas, internacionais e nacionais, buscam a cidade no intuito de ter um aprendizado sobre como é a vida do carioca.

O TBC surgiu para contrapor o turismo de massa, tendo como proposta mostrar ao turista os males que estavam ocorrendo devido à prática turística baseada no modelo urbano-globalizado e pós-industrial (NASCIMENTO, 2010). De acordo com a World Wildlife Fund - WWF ${ }^{1}$ (2001, p. 2) dois processos foram iniciados quando o turismo começou a ser usado estrategicamente como ferramenta para reduzir a pobreza na década de 1980, esses foram: Ecoturismo e Turismo de Base comunitária. A ideia continua sendo principalmente, a promoção do turismo envolvendo direta e indiretamente as localidades que residem ou estão próximas de áreas de conservação.

Os projetos de TBC têm como objetivo básico o progresso da condição de vida dos autóctones (MIELKE; PEGAS, 2013), a partir de uma modalidade turística que se desenvolve pelos próprios moradores locais, que projetam atividades, operações e

\footnotetext{
${ }^{1}$ World Wildlife Fund - WWF, é uma ONG (organização não governamental) internacional, que atua na área de conservação e preservação da natureza, com o objetivo de harmonizar a atividade humana com a conservação da biodiversidade e promover o uso racional dos recursos naturais em benefícios dos cidadãos de hoje e das futuras gerações. (WWF - Brasil, 2012, p. 4).
} 
empreendimentos em um município receptor de visitantes. É uma alternativa de modelo ao turístico convencional que favorece a preservação do modo de vida tradicional e a biodiversidade de pequenas áreas, além de instigar a economia local (ALBRECHT, 2011). Para Rodrigues (2003, p. 54), é uma atividade econômica, com baixo embate ambiental, que é beneficiada pela sua cultura e ambiente local, assim se aproveitando de seus próprios valores, de forma que os projetos educativos contribuem para a preservação da diversidade social, resultando em benefícios para o povo receptor.

Carvalho (2007) afirma que, uma vez que o número de visitantes cresce nesse modelo de turismo, os povoados que os recebem devem se organizar e agregar-se aos demais segmentos turísticos que podem ser desenvolvidos no local. Diante deste contexto o TBC aproxima visitante, destino e comunidade. Entende-se, então, que o TBC é aquele em que a população local, de forma comunitária, organiza arranjos produtivos locais ${ }^{2}$, tendo o domínio sobre as atividades que geram a economia turística na localidade e de suas terras (CORIOLANO, 2009). Esse modelo de turismo que, de acordo com o Ministério de Turismo (BRASIL, 2010), além de proporcionar melhorias de renda para a comunidade envolvida, viabiliza a preservação da localidade natural do local, pois as atividades oferecidas influenciam a proteção das áreas ambientais ao redor e dentro da locação, através das maneiras sustentáveis, ultimando que o molde de sobrevivência de cada recinto deve ser bem idealizado para que esses projetos deem certo e valorizem o seu meio ambiente.

O turismo comunitário não se destaca apenas como uma atividade produtiva, mas procura exercer um papel fundamental de ética e cooperação nas relações sociais, valorizando os recursos do território e buscando estabelecer relação de comunicação com turistas e a comunidade receptora (SAMPAIO, 2006). Segundo Sampaio e Coriolano (2009), o TBC é pensado como um projeto de desenvolvimento territorial sistêmico e sustentável, a partir da própria comunidade local. Ou seja, esse modo de turismo fomenta a relação social entre modos de vida distintos, resgatando o interesse pelo outro, pelo diferente, pelo autêntico (GRIMM; SAMPAIO, 2011).

\footnotetext{
${ }^{2}$ O Arranjo de Produto Local (APL) do turismo contribui para o crescimento econômico porque colabora para o surgimento de empresas, aumento da oferta de empregos, aumento da riqueza e da renda da população, além de benefícios sociais que o mesmo gera. O APL do setor turístico engloba empresas do subsetores alimentícios, hospedagens, agências de viagens, guias turísticos, transportes e demais operadoras que prestam serviços turísticos. (PIRES; CASTRO, 2015, p. 1).
} 
Projetos de educação ambiental e de preservação do meio ambiente e da cultura local são atividades que se expandem nas comunidades onde se é realizado o TBC. Essa atividade demanda e busca suporte do Poder Público e suas Políticas Públicas, pois há demanda de construções de infraestrutura de apoio ao serviço turístico, tudo dentro de uma lógica sustentável (MIELKE; PEGAS, 2013).

A participação do poder público proporciona para o turismo, entre outras medidas, a regulamentação das atividades a fim de gerar um possível controle sobre o desenvolvimento econômico e sociocultural equilibrado. Por essa razão, o poder público não pode ser indiferente. "Muitas vezes o turismo está sujeito à intervenção governamental direta e indireta em decorrência das possibilidades de geração de emprego e renda que apresenta e, portanto, do seu potencial de diversificar e contribuir para as economias nacionais e regionais.” (HALL, 2001, p. 39).

\footnotetext{
Uma política pública de turismo pode ser entendida como um conjunto de intenções, diretrizes e estratégias estabelecidas e/ou ações deliberadas, no âmbito do Poder Público, em virtude do objetivo geral de alcançar e dar continuidade ao pleno desenvolvimento da atividade turística num dado território (CRUZ, 2001, p. 40).
}

Sendo assim, o Estado pode contribuir de maneira significativa para com o turismo, uma vez que é quem atua como supervisor das atividades do mercado. Segundo Cruz (2002), a interposição nos aspectos sob a vida social em volta do Poder Público pode ser dividida em diversas modalidades, que podem ser encaixadas em indução, participação e controle.

Na categoria indução, o Estado atua para o estímulo de certas iniciativas sendo um orientador para a oferta de mercado e implantador de infraestrutura; na modalidade participação, o Estado pode exercer atividades econômicas dentro do setor do turismo. E, na modalidade de controle, o Estado exerce "o controle de aplicar e estabelecer as regras para a iniciativa privada que atuam na atividade turística, ou seja, atividades originalmente compartilhadas ao setor privado, contribuindo para agente de setor econômico.” (BARROS, 2010, p. 1).

Um dos grandes desafios para o TBC é ser um programa de governo, em domínio nacional de desenvolvimento turístico, que atenda as diversidades socioculturais e ambientais do país. Sob a perspectiva desse turismo em si, o TBC só se difere em uma relação comercial: algo se vende e se compra, criando assim, 
expectativas em torno dos serviços vendidos. (MIELKE; PEGAS, 2013). Os projetos do TBC devem gerar lucro para sustentar as iniciativas turísticas da comunidade como também nos projetos vinculados para melhorias de vida dos moradores locais. Essas atividades podem ser feitas de curto a longo prazo e devem ser discutidas e inseridas no plano de manejo do TBC $^{3}$ em todas as suas fases (MIELKE; PEGAS, 2013).

Todos esses projetos têm custos, onde a remuneração deve ser percebida e discutida antes da execução das atividades turísticas. Ou seja, de acordo com Mielke e Pegas (2013), se os projetos do TBC não contribuírem para o aumento do rendimento dos moradores, até 12 (doze) meses de sua efetivação, o mesmo não terá a confiança da comunidade e terá a sustentabilidade turística e econômica afetadas.

As iniciativas do Turismo de base comunitária devem ser concebidas, portanto, a longo prazo. Não seria possível preparar uma ou mais comunidades no período inferior de 12-24 meses. É fácil de se entender isso pelas expectativas do negócio turístico. A admissão ao mercado pode se tornar um problema quando a relação com os canais de distribuição não está corretamente estipulada ou não se encontra um meio de encontrar e atrair o público alvo (MIELKE; PEGAS, 2013). Ainda de acordo com estes autores (2013), o baixo acesso ao mercado é o que pode tornar os projetos do TBC não sustentáveis após o período de investimento.

Além dos problemas causados à comunidade em casos de mau planejamento, há também os riscos de danos ambientais em decorrência de tais limitações, como a não remuneração esperada para os moradores. Isso pode causar sérias anomalias à viabilidade do turismo na localidade (MIELKE; PEGAS, 2013, p. 5). Todavia, o TBC pode também oferecer boas vantagens para a comunidade que adquire esse modelo de atividade.

\footnotetext{
Sendo essa modalidade mantida no princípio da sustentabilidade econômica, ambiental, sociocultural, entende-se que o Turismo de Base comunitária (TBC) pretende inserir as populações tradicionais, trabalhadores locais como principais protagonistas do empreendedorismo local (NASCIMENTO, 2010, p. 3).
}

\footnotetext{
${ }^{3}$ Segundo a ICMBio (2016, p. 1): O manejo e gestão adequados de uma Unidade de Conservação devem estar embasados não só no conhecimento dos elementos que conformam o espaço em questão, mas também numa interpretação da interação destes elementos. Para o TBC o fundamental é proteger o meio ambiente do local, é importante que a comunidade tenha em seu plano o cumprimento com os objetivos da Unidade de conservação, orientação e gestão da Unidade de Conservação e definição de suas diretrizes, definição de plano de manejo, promover a integração das comunidades do entorno com a UC. (MASTER AMBIENTAL, 2013, p. 3).
} 
Ou seja, os moradores e os projetos organizados pelos mesmos são fundamentais para que o TBC seja cada vez mais reconhecido por todos aqueles que ainda têm dúvidas e receio sobre esse modelo de turismo. "Portanto, os princípios não buscam o lucro máximo, mas visam defender primeiramente os seus direitos como cidadãos e sua ancestralidade" (BARRETO FILHO, 2009, p. 6).

Uma grande influência que o TBC tem para os turistas é o encontro, contato com o morador (BARTHOLO, 2009), capaz de oportunizar tanto as trocas materiais quanto imateriais. As trocas materiais e imateriais estão relacionadas em cada parte onde o turista está sendo acolhido, desde o transporte até a troca de informações e experiências, capazes de gerar aprendizagem.

Desta forma, pode-se proporcionar ao visitante e visitado uma relação harmônica de modo a evoluírem o nível de pensamento. Isso acontece quando o turista visita uma diversidade de localidades, onde se pode aprender algo diferente em cada uma delas. Esse nível só aumenta com as informações que o visitante acaba adquirindo, já que esse é o objetivo de se conhecer uma comunidade em lugares como o Rio. O turista muda sua maneira de pensar cada vez que absorve uma história ou cultura diferente. Isso acontece com qualquer um, as vezes se pensa que se sabe das coisas e quando se aprende na realidade não é como se imaginava que seria. É o que acontece com o estrangeiro que pensa que a comunidade é de uma forma e quando escuta e vivencia sua história altera a sua visão a respeito da mesma.

Tendo em vista que cada comunidade tem sua diversidade, isto se torna um fator de grande importância, pois se leva em conta as histórias locais, lugares e personagens. Dessa forma, cada uma das iniciativas nas comunidades se torna única, apresentando seu diferencial em relação às demais.

\section{MORRO DO VIDIGAL: ENTRE A ROTINA E O TURISMO DE BASE COMUNITÁRIA}

Neste tópico, se traz uma abordagem acerca de como as histórias do Vidigal nasceram, se traz ainda como surgiu o nome do bairro e como o turismo teve seu crescimento acentuado durante esses anos. Comenta-se também sobre os eventos e 
acontecimentos que ocorreram e estavam ocorrendo no Vidigal, e os resultados obtidos com as entrevistas.

Cabe destacar que os depoimentos das entrevistas expostas neste tópico foram obtidos por abordagens aleatórias, pois conforme a visita se estendia, a intenção era a de ir adentrando a comunidade e interagir com moradores, buscando sanar curiosidades e aprender mais sobre a história e acontecimentos do bairro. Contou-se com a colaboração da maioria dos 15 entrevistados, mas cerca de quatro a cinco pessoas não aceitaram falar, com quem houve tentativa de conversa, mas considerou-se possível perceber como o morador tinha satisfação de falar sobre o Vidigal, mesmo não sendo sobre pontos positivos.

O Morro do Vidigal se caracteriza como uma das mais significativas favelas do Rio de Janeiro no que tange à sua localidade. A área começou a ser ocupada em 1941, embaixo da Avenida Niemeyer até a praia do Vidigal (JOHAN, 2014, p. 1). O local possui uma longa história relacionada com os bairros nobres ao redor, e sua população já protagonizou eventos importantes para a história do Brasil. Como a visita do primeiro pontífice a pisar em terras brasileiras em 1980, o Papa João Paulo II; um dos principais projetos da comunidade, o "Nós no Morro"; entre outros. (LUCENA, 2016).

Segundo o jornalista Felipe Lucena, do site Diário do Rio (2016), o nome do bairro veio antes de a comunidade surgir. Nos meados do século XIX um guarda real da Polícia da corte, que se chamava Miguel Nunes Vidigal, assustou muita gente nas ruas do Rio de Janeiro (DIÁRIO DO RIO, 2016). Ninguém sabe como o nome do ex-policial fora dado ao bairro, porém, relatos elegem que monges deram de presente a Miguel Nunes as terras onde se encontra o "Morro do Vidigal", antiga "Chácara do Vidigal (DIÁRIO DO RIO, 2016).

Até os anos 1960, a região era conhecida como 'Portão do Anglo', em referência ao Colégio Anglo-Brasileiro, instalado ali em 1911, ou como 'Favela Rampa da Niemeyer' (LUCENA, 2016). O desenvolvimento em volta do bairro, com a construção da Avenida Niemeyer, em 1922, e os bairros Leblon e Ipanema, em 1960, favoreceram para o crescimento físico e populacional do Vidigal (LUCENA, 2016).

Todavia, após diversos acontecimentos, o Morro do Vidigal passou a ser visto como a "Favela dos artistas", devido à fundação do grupo "Nós no Morro", em 1986 (LUCENA, 2016). Durante todos esses anos de atuação, o grupo atingiu sucesso 
revelando artistas talentosos. Outra atividade reconhecida, na comunidade do Vidigal, foi a visita do Papa João Paulo II, em 1980. “A capela São Francisco de Assis, na região do Vidigal, passou a ser chamada de 'Capela do Papa', que possui uma placa exposta, lembrando esse dia histórico para todo o povo brasileiro" (LUCENA, 2016).

Verificou-se que o que mais estava popularizando a comunidade eram as festas nos albergues no topo do Morro, onde se pode visualizar de forma panorâmica a vista da cidade. Todavia, o turismo já faz parte da vida social do Vidigal há alguns anos, por volta da década de 1980 (VIDIGA, 2010), quando o morro era constantemente visitado por turistas em busca principalmente de diversão, como os bailes do Clube Águia, conforme contou uma moradora da comunidade em visita de campo. O Clube Águia era um espaço onde moradores curtiam os bailes em épocas onde ainda não havia a Unidade de Polícia Pacificadora - UPP instalada na comunidade (VIDIGA, 2010). Um morador ${ }^{4}$ explicou que o clube era um bom espaço para diversão de residentes e visitantes, onde os bailes eram organizados pela Associação de Moradores. O espaço foi vendido para a Igreja Universal que passou a atuar no bairro.

De acordo com outro morador ${ }^{5}$, as visitas começaram a aumentar quando os visitantes foram redescobrindo o morro, no fim da guerra entre facções ${ }^{6}$, por volta de 2006. Muitos curiosos passaram a subir a comunidade e descobrir um lugar diferente com uma paisagem deslumbrante, isso após os conflitos armados cessarem.

O processo de "turistificação" do Vidigal aconteceu lentamente, a partir do fim da guerra entre facções e a entrada da UPP (Unidade de Polícia Pacificadora). Com a redução dos confrontos armados, os turistas começaram a subir o morro e descobrir um lugar com uma bela vista e grandes atrativos culturais. (MIRANDA; FORTUNATO, 2016, p. 9)

Freire-Medeiros (2006) afirma que as comunidades cariocas começaram a ser reconhecidas como um atrativo de turismo após a visita do cantor Michael Jackson no

\footnotetext{
${ }^{4}$ Homem, 72 anos, morador do Vidigal há 65 anos, aposentado, ensino médio incompleto, viúvo, morando sozinho.

${ }^{5}$ Homem, 45 anos, Morador do Vidigal há 45 anos, Eletricista, ensino médio completo, possuindo até dois salários mínimos, morando com a esposa e dois filhos.

${ }^{6}$ Facções, na fala do morador, representa uma espécie de poder paralelo, "grupo de indivíduos partidários de uma mesma causa em oposição à de outros grupos [...] na modernidade, o termo passou a designar grupos antagônicos que disputam a supremacia política" e lutam para manter o próprio território. (DICIONÁRIO HOUAISS DA LINGUA PORTUGUESA, 2009).
} 
morro Santa Marta, em 1996. Segundo a autora, o turista está em busca de algo que desconhece em uma determinada propriedade, tentando enxergar o exótico e diferencial naquilo que é normal para o morador que já lhe é habitual. Portanto, esse tipo de turismo leva esse turista curioso a querer conhecer mais sobre uma comunidade, e já que nessas localidades pode-se ter uma renda menor de hospedagem, o visitante se agarra à oportunidade de se hospedar em uma localidade mais simples e aconchegante.

\footnotetext{
Ao contrário de hotéis que oferecem muito conforto, os morros oferecem experiências diferenciadas e paisagens panorâmicas a preços mais acessíveis. Turistas que já se hospedaram, voltam ou indicam para amigos. Como os outros meios de hospedagem da cidade, os albergues em favelas possuem um alto índice de ocupação na alta estação. (MIRANDA; FORTUNATO, 2016, p. 7).
}

No ano de 2016, ano dos jogos Olímpicos Mundiais, muitos turistas estrangeiros e também brasileiros buscaram se hospedar em albergues e hostels nas favelas pacificadas no Rio de Janeiro durante os jogos (GANDRA, 2016). Conforme a Associação de Cama e Café e Alguergues do Rio de Janeiro (2016, apud GANDRA, 2016), era esperada uma ocupação de $84,7 \%$ dos hostels na favela. Turistas estrangeiros foram os que mais se manifestaram em procurar esse meio de hospedagem, cerca de 70\% dos ocupantes. De acordo com Gandra (2016), Adam Newman, norte americano, dono do Hostel Favela Experience, no morro do Vidigal, contou que abriu a agenda no mês anterior e que a lista de espera era bem ampla. Também durante as olimpíadas, o Vidigal testemunhou um grande aumento de turistas na trilha Dois Irmãos, uma atração popular na comunidade (GRANDA, 2016). A trilha era um tesouro local, cuidada e visitada principalmente por moradores locais, mas depois da instalação da Polícia pacificadora, passou a ser uma das mais frequentadas do Rio (MCALLISTER; CRONIN, 2016, p. 1).

O termo "comunidade do Rio de Janeiro" muitas vezes é relacionado à violência e insegurança, mas, além disso, como esclarece Freire-Medeiros (2009), o morador da favela por si próprio a define como comunidade devido ao desenvolvimento dentro dela e a inclusão social. De acordo com essa autora, "a favela emerge como um território autossuficiente, portador de cultura própria, em que os habitantes se mantêm unidos em oposição à sociedade egoísta que os cerca” (FREIRE-MEDEIROS, 2009, p. 96-97). 


\subsection{TURISMO NO VIDIGAL: ENTRE OS BENEFÍCIOS E OS ENTRAVES}

O Morro do Vidigal permite que o turista tenha várias possibilidades e meios de conhecer a comunidade e seus atrativos. O roteiro passaporte verde no Vidigal, por exemplo, é uma das atividades existentes no bairro. Criado pelo Favela Experience ${ }^{7}$, o roteiro pode ser feito por um ou dois dias. A excursão começa no Parque Ecológico Sitiê, no alto do morro.

É um local de pura natureza, com mais de oito mil metros quadrados, com variadas espécies nativas da Mata Atlântica (PAVLOVA, 2016). Depois da visita ao parque, o roteiro segue, dependendo da disponibilidade dos artistas, com um show de percussão das "Meninas de Sol” (grupo formado por quatro moradoras da comunidade); em seguida, apresentação de capoeira com meninos e meninas que aprendem o esporte na Associação de Moradores local; visita ao hostel de impacto social Favex, que é um lugar onde se abrange um bom número de projetos sociais para a comunidade e para receber o visitante. $\mathrm{O}$ Favex oferece alguns projetos que ajudam muito na conservação e melhoria do bairro, como: SER Alzira de Aleluia; Batukavi e Favela + verde (PAVlOVA, 2016). Mais uma visita interessante e a oportunidade de poder acompanhar um ensaio do projeto "Nós no Morro" (FAVELA EXPERIENCE, 2016).

O roteiro também conta com uma parte voltada para a arte, onde os visitantes podem conhecer a padaria-bistrô-galeria de arte, Baixo Vidigal Galeria. Além de poder apreciar as fotografias e das exposições de arte, é oferecido para os visitantes lanches e sucos feitos pelos próprios moradores (PAVLOVA, 2016, p. 2). A Favela Experience também organiza outros roteiros culturais e sociais dentro do bairro, com atividades para turistas, voluntários e estudantes (BRASIL, 2016).

André Gosi, diretor cultural e social da Associação de moradores do Vidigal, explicou para Ahmed (2015, p. 1) que:

[...] o futuro do Vidigal significa também olhar para o passado; o Vidigal dos anos 1980 era muito bom! Nós queremos reanimar essa identidade, dar uma olhada para essa origem. É muito importante sair do traumatismo e do medo com projetos de arte, de festa, para revitalizar o Vidigal.

\footnotetext{
${ }^{7}$ Favela Experience é uma empresa de turismo de impacto social que busca conectar pessoas, ideias e recursos globais com moradores, organizações e serviços das favelas através de experiência e espaços autênticos e imersivos. Querendo romper estereótipos por meio da promoção de intercâmbio cultural e colaboração social, para que a favela seja protagonista de um turismo responsável. (FAVELA EXPERIENCE, 2016). Disponível em: <https://www.favelaexperience.com/>. Acesso em: 26/06/2018.
} 
Além dos já citados, constatou-se pessoalmente haver inúmeros projetos e trabalhos voluntários que inspiravam turistas e moradores, como acontece com o projeto Casa Geração, que consiste em fornecer aulas de corte e costura para moradores e estudantes. A Casa Geração foi criada por uma francesa, que trabalha com comunidade cariocas acerca de oito anos. A casa é aberta a todos gratuitamente e conta com voluntários de escolas de moda da França, explicou Jessica Senra, uma das alunas do curso que acompanhou uma das autoras na visita de campo ao Morro do Vidigal e nas entrevistas com os moradores.

Verificou-se que as atividades no morro do Vidigal estavam sendo bem amplas, desde trilhas a festas no topo do morro. Em visita à comunidade, moradores contaram como era constante a visita de turistas no bairro. Segundo eles, não havia um dia em que um "gringo" ou até mesmo turistas brasileiros não aparecessem para conhecer as belezas e histórias do local.

Por conta dessas frequentes visitações, notou-se que alguns projetos desenvolvidos no Morro do Vidigal estavam contribuindo para implantar o Turismo de Base comunitária, de modo a gerar melhorias na condição de vida do próprio bairro, auxiliando no desenvolvimento da renda dos moradores.

Um dos principais projetos dentro desta perspectiva foi a criação do Parque Ecológico Sitiê, no alto do Morro, criado pelos próprios moradores (entre eles o próprio idealizador, Mauro Quintanilha), juntamente com um ex-aluno formado em políticas públicas, Pedro Henrique. (GOMIDE, 2013). Durante mais de vinte e cinco anos, a área onde está situado o Parque, era local de acúmulo de lixo. Mauro Quintanilha, morador do Vidigal, afirmou que obteve a ajuda de alguns amigos. "Em 2013, Pedro Henrique buscou transformar o projeto de Mauro em um parque ecológico e de educação, voltado para a conservação e sustentabilidade.” (GOMIDE, 2013, p. 2) Pedro chamou alguns amigos arquitetos que o ajudaram na elaboração dos projetos sustentáveis.

Nesta perspectiva, desde 2010 e até cinco anos depois, foi possível verificar a retirada de mais de dezesseis toneladas de lixo (BRISSOLLA, 2013). Assim, o lixão deu lugar ao Parque Ecológico Sitiê, já apresentado anteriormente. No espaço foi plantada uma horta, ainda cultivada e na qual já foram coletados mais de 700 quilos de legumes, verduras, temperos e frutas (BRISSOLLA, 2013). A horta é aberta para voluntários que desejam manter o parque como uma fonte de sustentabilidade e 
moradores que ajudam também colhem os frutos. "Não tivemos ajuda de governo. Minha família dizia que eu era maluco, mas acabamos atraindo voluntários, gente daqui e turistas estrangeiros. Depois consegui mudas do Jardim Botânico e fiz o paisagismo, tudo intuitivamente", sendo isso que Quintanilha contou para Pennafort (2015, p. 1).

Constatou-se que a comunidade ainda realizava alguns eventos para divulgar trabalhos de artesãos locais, como A Feira de Artesãos do Vidigal (AHMED, 2015). Moradores, durante entrevista de campo, relataram que muitos estrangeiros passaram a morar no Vidigal. Segundo eles, estes visitantes foram chegando e foram ficando. Passaram a contribuir em trabalhos voluntários e, aos poucos, foram se inserindo de tal forma que passaram a compartilhar suas próprias experiências com outros turistas que iam chegando.

Posteriormente, além de trabalhar em áreas de conservação no Morro do Vidigal, o turista tem a oportunidade de interagir e conviver com os moradores locais, mas nem sempre os dois lados estão em comum acordo. Uma das moradoras ${ }^{8}$ entrevistadas contou que:

[...] há muitos vizinhos e conhecidos que alugam suas casas ou quartos para turistas, mas alguns desses turistas não respeitam a casa alheia e fazem muita baderna. Mas mesmo assim, ainda existem muitos moradores que possuem hospedagem na localidade, e às vezes, o morador prefere hospedar um gringo, que paga muito mais, do que um residente local.

Observou-se que a grande maioria dos moradores, cerca de 94\%, estava possuindo algum tipo de comércio na localidade. Muitos relataram que era para ajudar com os gastos de moradia, que se tornaram mais caros depois do reconhecimento da comunidade. Tal episódio foi explicado pelas muitas obras concebidas dentro das favelas para o turista. Apesar de alguns desses entraves, todos os moradores que participaram da pesquisa, afirmaram que não sairiam do Vidigal para morar em outro lugar.

Os tipos de comércios estavam sendo dos mais diversos, desde lojinhas até restaurantes. Como a badalada casa da pesquisadora de nutrição, Maria das Graças. Mais conhecida como Graça dos Prazeres, que cozinha sua típica comida na frente dos

\footnotetext{
${ }^{8}$ Mulher, 45 anos, Moradora do Vidigal há 45 anos, Comerciante e Diarista, ensino médio incompleto, possuindo até dois salários mínimos, morando com filha; marido e duas netas.
} 
turistas, misturando sementes e alimentos crus (PAVLOVA, 2016). Seu espaço estava sendo vinculado com o passaporte verde da Favela Excipiente, para os turistas aventureiros que faziam a trilha no Vidigal. "O Passaporte Verde dá visibilidade às minhas pesquisas, que envolvem cozinha orgânica e detox, por meio da alimentação saudável. Depois, quem tiver interesse pode voltar para um fazer um curso mais detalhado" (PAVLOVA, 2016, p. 2).

A partir do diário de bordo elaborado em visita a campo, foi possível notar que a vida na comunidade do Vidigal nunca ficava pacata. Numa das visitas realizada na comunidade, em um dia ensolarado de domingo, não se pôde deixar de observar muitos moradores que desciam o morro para ir à praia. Havia muita gente na rua e sempre um cumprimentava o outro. Logo na entrada do bairro, um grande movimento de mototaxis (serviço de transporte alternativo), e os policiais da UPP que também estavam ali. Subindo o morro, a pé, notou-se grande movimentação. Uma das moradoras e comerciante local ${ }^{9}$, relatou que o transporte dentro da comunidade era perigoso, os preços dos mototaxis variavam entre morador e turista. A rua era estreita e não havia calçada para os pedestres que estavam sempre em litígio com os motoristas dos meios de transportes que levavam moradores e turistas para o topo. Taxis ou motoristas do Uber $^{10}$ não subiam o morro. Por isso, muitos turistas escolhiam subir de Kombi ou de mototaxi, e por não serem do local acabavam pagando um preço maior que o do morador.

A mesma moradora acabou contando vários acontecimentos do dia a dia da comunidade, como por exemplo, o convívio com a Polícia Pacificadora. Segundo ela, inicialmente:

[...] todos gostaram muito da ideia da implantação da UPP, mas na realidade não mudou muita coisa. É fato que a violência e o armamento desapareceram das vistas de todos, mas como toda a comunidade o consumo de drogas é constante. Os policias não têm muito respeito com os moradores e, às vezes, reconhecem os usuários de droga e acabam agredindo eles na frente de todos.

\footnotetext{
${ }^{9}$ Mulher, 55 anos, Moradora do Vidigal há 40 anos, Comerciante, ensino médio completo, não possuindo uma média salarial exata, morando com o marido e filhos.

${ }^{10}$ Uber é uma empresa multinacional americana de transporte privado urbano que utiliza um aplicativo para comunicação entre o passageiro e motorista particular associado ao Uber. É um serviço semelhante ao táxi tradicional, conhecido popularmente como serviços de "carona remunerada" (UBER, 2016). Disponível em: <https://www.uber.com/pt-BR/>. Acesso em: 26/06/2018.
} 
De acordo com Carvalho (2013), houve uma centralização das ações no cotidiano dos moradores da favela e de alguns dos problemas que moradores passaram a enfrentar após a ocupação. Isto é, essa centralização pode vir a conceber um autoritarismo por parte da UPP, à medida em que essa organização determina as ações de acordo com que o comando acredita representar a ordem no bairro. "Sendo assim, há um aumento de relatos de moradores de favela sobre o abuso da autoridade e de uma violência visível protagonizada por alguns dos policiais que realizam abordagens injustificadas, agressões verbais e físicas" (CARVALHO, 2013, p. 285-308).

Mesmo com problemas no cotidiano da comunidade, o bairro não estava deixando de ser cobiçado por moradores externos que para lá se mudavam constantemente. Um outro morador ${ }^{11}$ relatou que todos os dias havia obras em toda parte, tanto para de casas como de outras construções. Sobre isto considerou-se interessante fazer um paralelo com os dados obtidos em pesquisa feita pela estudante da UERJ (Universidade do Estado do Rio de Janeiro), Miriene Peregrino (2015). Segundo um residente informou a ela, mesmo com o número de obras elevado no Morro, as obras eram para os gringos, para os hostels, pois os moradores mesmo não tinham condições de fazer obra de tal tamanho e a toda hora.

Todavia, considerou-se pertinente mencionar que ainda assim verificou-se haver benefícios que o turismo estava trazendo para a comunidade, como a melhoria na infraestrutura. Ainda em conversa com a comerciante local, relatada anteriormente, obteve-se a informação de que: "o número de casas cada vez cresce mais, e todo dia aparecem pessoas diferentes. Hoje em dia é muito difícil saber quem mora aqui e quem está apenas de visita".

A maioria dos moradores entrevistados, no entanto, disse que muitos turistas queriam somente saber de festas e das trilhas. Tais residentes reconheceram o potencial que a comunidade tinha, com seus projetos e a grande expressividade cênica de sua natureza, mas relataram que quem ganhava mais com a movimentação do turista na favela eram os empreendedores que atuavam no alto do morro.

De acordo com os autores Renato Meirelles e Celso Athayde (2014), era possível perceber que tal como em outras localidades, o turismo no Vidigal estava

\footnotetext{
11 Homem, 60 anos, Morador do Vidigal há 60 anos, Comerciante, ensino médio incompleto, não possuindo uma média salarial exata, morando com a filha.
} 
gerando alguns aspectos sociais, como o aumento da renda salarial de alguns. Com isso, os autores explicaram que o ritmo turístico nas favelas aumentou. Verificou-se haver muitos moradores de classe média nas favelas (65\%), mais do que na média do Brasil como um todo (54\%). A média salarial de um morador da favela aumentou $54,7 \%$ de 2003 a 2013, passando a ser a mesma do Brasil, 37,9\%. (MEIRELLES; ATHAYDE, 2014).

No entanto, segundo informações de uma comerciante local, não havia como um morador participar das festas que ocorriam na parte alta do morro, sendo caras para eles. Além de não serem acessíveis para os autóctones, chegavam a durar a madrugada toda, quiçá dias. “Às vezes, quando a associação de moradores faz evento para nós moradores ou até mesmo em nossas casas, a UPP não deixa que fique até tarde, enquanto que nas festas lá em cima, para os bacanas, dura até altas horas".

Em comparação com as entrevistas feitas pela estudante da UERJ, em 2015, e esta, em 2016, se fez possível notar que ainda havia muitos moradores que reclamavam sobre as mesmas coisas. A favela era bem vista "de fora", como um método de turismo que estava sendo cada vez mais popular para o turista, mas ainda havia uma barreira entre os moradores e o visitante.

Como pontos negativos, os participantes de ambas pesquisas relataram que a comunidade estava sofrendo com a constante ida de turistas, havendo muito desmatamento e lixo pelo caminho. Outro ponto que persistiu foi o fato de haver muitos imóveis sendo alugados por moradores antigos, como já dito anteriormente. Muitos residentes estavam obtendo renda a partir do aluguel de quartos, conseguindo, inclusive, construir mais quartos para os turistas. "Quem antes tinha que trabalhar fora, em casa de família no Leblon ou Ipanema, desde que começaram a alugar quartos, não precisam mais trabalhar fora da comunidade, o que é bem favorável para tal morador", relatou uma das entrevistadas ${ }^{12}$.

Observou-se, pelos relatos dos entrevistados, que os impactos físicos e socais do turismo de massa descontrolado começavam a preocupar moradores, observando também o impacto negativo ambientalmente desregulado provocado pelo visitante a espaços de preservação. "Começa então a se falar sobre os limites físicos das

12 Mulher, 55 anos, Moradora do Vidigal há 40 anos, Comerciante, ensino médio completo, não possuindo uma média salarial exata, morando com o marido e filhos. 
localidades que sofrem com o efeito despreocupado dos alheios, de capacidade de carga; com a fronteira da natureza e a improdutividade do turismo de massa nas favelas do Rio de Janeiro" (SPAMPINATO, 2009, p. 7).

\begin{abstract}
O turismo na favela pode ser percebido como um elemento de valorização local e a promoção desse destino, a "pobreza turística" que, por um lado beneficia o mercado local, muda as imagens midiáticas e modifica o que era feio para exótico, por outro lado, aumenta a disputa pelo território e a especulação imobiliária muda toda forma econômica, social e cultural. (MIRANDA; FORTUNATO, 2016, p. 8).
\end{abstract}

Em suma, considera-se ser inevitável aceitar que a implantação da UPP melhorou, em partes, a vida do morador na comunidade, promovendo a aceleração da ocupação do morro. A comunidade do Vidigal sempre foi disputada em termos de moradia devido à sua localização, tendo-se verificado durante a pesquisa, que a especulação imobiliária havia aumentado. Os residentes mais antigos estavam encontrando dificuldade de continuar vivendo em um local onde o custo de vida estava se tornando cada vez maior. Mesmo assim, os moradores disseram que continuariam na comunidade e, por isso, tentavam garantir a sobrevivência através do comércio.

Como alternativa às problemáticas apresentadas, cabe destacar que o crescimento do TBC na localidade, se adequadamente praticado, comercializado e regulamentado poderia representar um incentivo aos habitantes locais. Neste sentido, a solidificação da estrutura em torno deste segmento pode representar uma alternativa de sua consolidação não apenas no Morro do Vidigal, como nas demais favelas do Rio de Janeiro.

Em 2015, o vereador Célio Lupparelli (DEM) propôs o PL 1599/2015, que visa tornar algumas favelas em Áreas de Especial Interesse Turístico (AEIT). Em conversa com moradores e guias locais, entendeu que devia fazer um projeto de lei que incentivasse o turismo de base comunitária. "Nosso turismo tem que ser feito pela base. Nada de exploração externa", afirma Thiago Firmino, guia local da Favela Santa Marta e componente da Associação de Guias Locais de Favelas (AGLF). Thiago também é um dos entusiastas da lei, que ainda está parada na Câmara. (ANF, 2018, p. 2).

\title{
4 CONSIDERAÇÕES FINAIS
}

Na pesquisa apresentada se abordou a construção de um segmento não muito conhecido pelas pessoas, o Turismo de Base Comunitária, em destaque no Morro do 
Vidigal, no Rio de Janeiro. O Turismo de Base comunitária é um trabalho complexo e de longo prazo, a fim de se aprofundar e permitir a melhoria de vida das pessoas envolvidas (MIELKE, 2013).

Neste sentido, considerou-se que se atingiu o objetivo geral proposto ao demonstrar que o TBC no morro de Vidigal estava sendo muito visitado e popular. Todavia, enfrentava alguns problemas com a comunidade, que muitas vezes não era adequadamente valorizada pelo visitante. A ideia desse segmento nas comunidades do Rio de Janeiro resulta em unir o dia a dia dos moradores para o aprendizado e o voluntariado dos turistas interessados, tentando assim, promover o turismo no bairro, favorecendo os moradores.

Em relação aos objetivos específicos, foi possível atingi-los à medida que notouse o Morro do Vidigal como uma localidade que, externamente, desenvolve um tipo de turismo popular, ao mesmo tempo em que, internamente, é um local que se expande a cada dia, vivenciando diversos acontecimentos, desde a UPP até os altos níveis imobiliários. Nesta perspectiva, os moradores do bairro se mostraram muito preocupados em manter o status de umas das favelas mais visitadas do Rio de Janeiro, ao mesmo tempo em que demonstraram querer manter e cooperar com os projetos sociais que estavam se expandindo visivelmente. No entanto, percebeu-se que no Vidigal havia um outro lado, onde atuavam empresários que exploravam a beleza do local trazendo turistas somente para seus benefícios. Este último estava agregando muito mais visitantes do que o esperado para a comunidade em si, dando mais oportunidades para os externos, que investiam na localidade, que para seus próprios habitantes.

A hipótese inicial se desvencilhou conforme a pesquisa se aprofundava, contrapondo uma realidade do turismo no Morro do Vidigal um tanto quanto diferente quando dita pelo morador da localidade, que insistiu no fato de que quem era mais valorizado estava acima deles. Entretanto verificou-se ainda haver moradores, com a ajuda desses estrangeiros e voluntários que se encarregavam de manter o turismo mais voltado à sustentabilidade do bairro. Assim, o TBC estava crescendo ao redor dos que queriam lucrar com esse segmento, embora não muito bem planejado com os demais empreendedores locais, tendo em vista que cada um tinha o seu negócio, tendo uma renda individual sem contribuir para a comunidade. 
O principal objetivo desta pesquisa foi apresentar o Turismo de Base Comunitária como uma oportunidade de exercer atividades que demonstrassem ao visitante um novo meio de turismo, favorecendo o nome da comunidade e trazendo melhorias para moradores locais. Sobre este aspecto, alguns moradores, cerca de $20 \%$, disseram que os projetos desenvolvidos no Morro ajudaram muitas pessoas. Tais projetos estavam atraindo tanto o residente local quanto o estrangeiro, que estivesse disposto a contribuir com suas experiências. Demonstrando-se assim, que o Vidigal estava possuindo um potencial expressivo para exercer com mais profundidade o segmento do TBC, com a contribuição da paisagem única e das atividades turísticas que estavam sendo exercidas no bairro, como as excursões e a trilha.

Considerou-se ser possível perceber o quanto o TBC estava sendo um segmento que, se bem planejado e executado, poderia contribuir com a comunidade. $\mathrm{Na}$ visão destas pesquisadoras, o Vidigal poderia estar sendo pouco valorizado, com problemas contínuos sobre os empreendimentos no alto do morro que não contribuíam para os moradores. Isto demonstrou que o Vidigal possuía duas realidades. Ou seja, mesmo que alguns dos projetos fossem ideia de um externo, sempre haveria um morador para fazer parceria, talvez assim a comunidade mudasse de tal modo que todos pudessem ser beneficiados com o turismo local.

Em suma, com a cooperação no campo das atividades turísticas na localidade, considerou-se correto o modo de se lidar com negócios que poderiam contribuir tanto com ganhos individuais quanto coletivos. Para isso, seria preciso estabelecer regras e processos através dos quais se poderia contribuir para a melhoria dos moradores locais, o que tornaria tudo um desafio constante para o desenvolvimento correto do turismo no bairro. Seria necessário também um planejamento específico para o TBC para que a comunidade viesse a ter um papel claro do turismo em suas realidades.

\section{REFERÊNCIAS}

AHMED, I. A Comemoração continua: 75 anos do Vidigal. Rio de janeiro: Rionwatch, 2015. Disponível em: <http://rioonwatch.org.br/?p=14075>. Acesso em: 04/12/2016. 
ALBRECHT, A. Seminário de Turismo de Base Comunitária nos Pantanais da rota norte região turística de Mato Grosso do Sul. 2011. Disponível em: $<$ https://www.kickante.com.br/campanhas/i-seminario-de-turismo-de-base-comunitariano-pantanal-da-rota-norte-regiao-turistica-de-0>. Acesso em: 20/11/2016.

ANF - AGÊNCIA DE NOTÍCIAS DAS FAVELAS. Turismo nas Favelas é alvo de iniciativas para regulamentação. Disponível em: <https: http://www.anf.org.br/turismo-nas-favelas-e-alvo-de-iniciativas-para-regulamentacao/> . Acesso em: 26/06/2018.

BARTHOLO, R. Sobre o sentido da proximidade: implicações para um turismo situado de base comunitária. In: BARTHOLO, R.; SANSOLO, D. G.; BURSZTYN,I. (orgs.). Turismo de Base Comunitária: diversidade de olhares e experiências brasileiras. Rio de Janeiro: Letra e Imagem, 2009. pp.45-54

BARRETO FILHO, L. E. Apresentação. In: BARTHOLO, R.; SANSOLO, D. G.; BURSZTYN, I. (Org.). Turismo de Base Comunitária: diversidade de olhares e experiências brasileiras. 1. ed. Brasil: Nova Letra Gráfica e Editora, 2009.

BARROS, L. Intervenção do Estado deve ter limites. Revista Consultor Jurídico, São Paulo, p. 1-14, 2010. Disponível em: <http://www.conjur.com.br/2010-fev07/intervencao-estado-fomento-cultural-limites>. Acesso em: 01/12/2016.

BRASIL, Ministério do Turismo. Turismo de Base Comunitária: diversidade de olhares e experiências brasileiras. Rio de Janeiro: Letra e imagem, 2009.

Ministério do Turismo. Dinâmica e Diversidade do Turismo de Base Comunitária. Brasília: Ministério do Turismo, 2010.

Ministério do Turismo. Programa de Regionalização do Turismo. Brasília: Ministério do Turismo, 2013.

Ministério do Turismo. Pesquisa de Caracterização e Dimensionamento do Turismo Internacional no Brasil. Brasília: Ministério do Turismo, 2015.

Ministério do Turismo. Pesquisa de Caracterização e Dimensionamento do Turismo Internacional no Brasil. Brasília: Ministério do Turismo, 2016.

BRISOLLA, F. Lixão em favela do Rio vira área de preservação ambiental. São Paulo: Folha de São Paulo, 2013. Disponível em: <http://www1.folha.uol.com.br/cotidiano/2013/12/1379104-lixao-em-favela-do-riovira-area-de-preservacao-ambiental.shtml>. Acesso em: 07/12/2016.

CARVALHO, M. A polícia de pacificação de favelas e as contradições para a produção de uma cidade segura. Revista O Social em Questão. Rio de Janeiro, n. 29, p. 285-308, 2013. 
CORIOLANO, L. N. M. T. Arranjos produtivos locais do turismo comunitário: Atores e cenários em mudanças. Fortaleza: EdUECE, 2009.

CRUZ, R. C. Política de turismo e território. São Paulo: Contexto, 2001.

DANTAS, T. Passeio Rio uma aventura pelas belezas naturais da cidade. 2013. Disponível em: <http://www.guiadorio.net.br/2013/10/passeio-rio-jardim-botanicofloresta-da-tijuca.html>. Acesso em: 20/11/2016.

DICIONÁRIO HOUAISS DA LINGUA PORTUGUESA/ HOUAISS, ANTÔNIO; VILLAR, MAURO DE SALLES. Elaborado no Instituto Antônio Houaiss de Lexicografia e Banco de Dados da Língua Portuguesa S/C Ltda - Rio de Janeiro: Objetiva, 2001.

FAVELA EXPERIENCE. Favelidade - Rio, 2016. Morro do Vidigal - cortejo cultural. Disponível em: <https: https://www.favelaexperience.com/favelidade>. Acesso em: 26/06/2018.

FREIRE-MEDEIROS, B. A construção da favela carioca como destino turístico. Rio de Janeiro: CPDOC, 2006.

FREIRE-MEDEIROS, B. Gringo na laje: produção, circulação e consumo da favela turística. Rio de Janeiro: Editora FGV, 2009. 164 p.

GANDRA, A. Com tarifa menor, turistas buscam albergues nas favelas para os jogos de 2016. Agência Brasil. Disponível em: <http://agenciabrasil.ebc.com.br/geral/noticia/2016-04/com-tarifa-menor-turistasbuscam-albergues-nas-favelas-para-a-Rio\%202016>. Acesso em: 26/06/2018.

GOMES, R. Viagem e Turismo: Rio de Janeiro. Rio de Janeiro: Editora Abril, 2016. Disponível em: <http://viajeaqui.abril.com.br/estados/br-rio-de-janeiro>. Acesso em: 27/11/2017.

GOMIDE, R. Conexão Vidigal-Havard - asfalto transforma lixão em parque educativo. Rio de Janeiro: 2013. Disponível em: $<$ http://ultimosegundo.ig.com.br/brasil/rj/2013-03-28/conexao-vidigal-harvard-asfaltotransforma-lixao-em-parque-educativo.html>. Acesso em: 06/12/2016.

GRIMM, I; SAMPAIO, C. Turismo de Base Comunitária: convivencialidade e Conservação ambiental. Revista Brasileira de Ciências ambientais. Rio de Janeiro, n. 19, p. 57-67. Mar, 2011.

HALL, S. A Identidade Cultural na Pós-modernidade. Rio de Janeiro: DP\&A, 2001.

JOHAN. Zona Sul - Vidigal. 2014. Disponível em: <http://offroad.student.utwente.nl/johan/rio/br/bairros/vidigal.htm>. Acesso em: 01/12/2016. 
KRIPPENDORF, J. Sociologia do turismo: para uma nova compreensão do lazer e das viagens. Rio de Janeiro: CIVILIZAÇÃO BRASILEIRA, 1989.

LUCENA, F. História do Morro do Vidigal. Rio de Janeiro: Diário do Rio, 2016. Disponível em: <http://diariodorio.com/histria-do-morro-do-vidigal/>. Acesso em: 02/12/2016.

MAGAlHÃES, A. F.; SOUTO CEZAR, L. F. O.; COCCARO, S. E.; FONSECA, P. R. O Mercado Imobiliário de aluguel em Favelas do Rio de Janeiro: "Informalidade" ou outras formas de formalidade. Rio de Janeiro, 2013. Disponível em: $<$ https://www.researchgate.net/profile/Sue_Coccaro/publication/308892073_423O_ME RCADO_IMOBILIARIO_DE_ALUGUEL_EM_FAVELAS_DO_RIO_DE_JANEIRO _INFORMALIDADE_OU_OUTRAS_FORMAS_DE_FORMALIDADE/links/57f54a1 a08ae91deaa5c78ed/4230-MERCADO-IMOBILIARIO-DE-ALUGUEL-EMFAVELAS-DO-RIO-DE-JANEIRO-INFORMALIDADE-OU-OUTRAS-FORMASDE-FORMALIDADE.pdf>. Acesso em: 26/06/2018.

MCALliSTER, N.; CRONIN, S. Aumento de turismo da trilha Dois Irmãos suscitam preocupação no Vidigal. Rio de Janeiro: Rioonwatch, 2016. Disponível em: <http://rioonwatch.org.br/?p=21937>. Acesso em: 02/12/2016.

MEIRELHES, R; ATHAYDE, C. Um país chamado favela: a maior pesquisa já feita sobre favela brasileira. São Paulo: Edita Gente, 2014.

MIELKE, E; PEGAS; F. Turismo de Base Comunitária no Brasil. Insustentabilidade é uma questão de Gestão. 1 ed. Rio de Janeiro: UERJ, 2013.

MIRANDA, I.; FORTUNATO, A. R. O turismo sobe o morro do Vidigal (Rio de Janeiro, Brasil): uma análise exploratória. Turismo \& Sociedade (ISSN: 1983-5442). Curitiba, v. 9, n. 2, p. 1-20, maio-agosto de 2016.

NASCIMENTO, R. Explanações sobre o Turismo de Base Comunitária no Município de Salvaterra. Pará: UFPA, 2010.

PAVLOVA, A. Jogos olímpicos e verde: roteiro especial de turismo sustentável no Rio, do morro do Vidigal à trilha do Mico-leão. Rio de Janeiro: Coca Cola Journey; 2016. Disponível em: <http://www.cocacolabrasil.com.br/historias/jogos-olimpicosverdes-roteiro-especial-de-turismo-sustentavel-no-rio-do-morro-do-vidigal-a-trilha-domico-leao>. Acesso em: 02/12/2016.

PENNAFORT, R. Parque ecológico no alto do Morro do Vidigal é premiado dos EUA. Rio de Janeiro: Estação Rio, 2015.

PEREGRINO, M. Vidigal: vidas e memórias em movimento - PARTE I. Rio de Janeiro: ANF - agencia de notícias das favelas, 2015. Disponível em: <http://www.anf.org.br/vidigal-vidas-e-memorias-em-movimento-parte-i/>. Acesso em: 04/12/2016. 
RIOTUR - Empresa de Turismo do Município do Rio de Janeiro. Turismo do Rio em números. 2015. Rio de Janeiro: RIOTUR, s. d. Disponível em: $<$ http://www.rcvb.com.br/noticias/riotur-apresenta-os-numeros-do-turismo-do-carnaval2017>. Acesso em: 26/06/2016.

RODRIGUES, A. J. Contextos de aprendizagem e integração? Inclusão de alunos com necessidades educativas especiais. In: RIBEIRO, M. L. S; BAUMEL, R. C. R. Educação especial: do querer ao fazer. São Paulo: Avercamp, 2003. p. 65-90.

SAMPAIO, C. A. C.; OYARZÚN, E. ; SOUXA, M. S. ; CÁRCAMO, C. ; MANTOVANELI JÚNIOR, O. Arranjo Socioprodutivo de Base Comunitária: análise comparativa de experiências de turismo comunitário no Brasil e no Chile. Anais IV SEMINÁRIO DE PESQUISA EM TURISMO DO MERCOSUL. Caxias do Sul, 7 e 8 de julho, 2006.

SPAMPINATO, E. Turismo em favelas cariocas e desenvolvimento situado: a possibilidade do encontro em seis iniciativas comunitárias. Rio de Janeiro: UFRJ, 2009.

VIDIGA. O Vidigal é... Rio de Janeiro: Vidiga, 2010. Disponível em: <https://vidiga.wordpress.com/vidigal/>. Acesso em: 05/12/2016.

WWF. WORLD WIDE FUND Guidelines for community-based ecotourism development. WWF International, 2001. Disponível em: <http://www.icrtourism.org/Publications/WWF1eng.pdf>. Acesso em: 17/11/2016.

Recebido em: 01-01-2018.

Aprovado em: 02-02-2018.

Publicado em: 11-08-2018. 